\title{
Partial sequence of the $g B$ gene of equid herpesvirus type 1 isolates associated with abortion in Turkey
}

\author{
Veysel Soydal ATASEVEN ${ }^{1}$, Tuba Çiğdem OĞUZOĞLU² ${ }^{2}$ Ender DİNÇER ${ }^{3}$, Seval BİLGE DAĞALP \\ ${ }^{1}$ Mustafa Kemal University, Faculty of Veterinary Medicine, Department of Virology, Hatay; ${ }^{2}$ Ankara University, Faculty of \\ Veterinary Medicine, Department of Virology, Ankara; ${ }^{3}$ Mersin University, The Center of Advanced Technology Education, \\ Research and Application, Mersin, Turkey.
}

Summary: Equid herpesvirus 1 (EHV-1) is a major agent of large-scale outbreaks of abortion, and these abortions have been described as sporadic or epidemic cases in mares, generally during the last trimester of pregnancy. In this study, the partial characterization based on the glycoprotein B $(g B)$ gene of Turkish (TR) EHV-1 field strains isolated from an abortion outbreak during the 2011 foaling season in Turkey was investigated using a novel designed primer set for EHV-1. The molecular analysis of TR EHV-1 strains showed that genetically identical TR EHV-1 strains were still circulating in Turkey during different years and, these strains were closely related to the European EHV-1 strains. Furthermore, EHV-1 isolated in the present study and to EHV-1 strains published previously in the GenBank database were shown some differences for the aa sequences. This molecular report would be valuable for monitoring of EHV-1 infection in Turkey and determining the $g B$ gene sequence of newly identified EHV-1 field strains from future outbreaks on the pathogenesis and severity of disease.

Keywords: Abortion, equid herpesvirus type 1 (EHV-1), glycoprotein B gene, horse, Turkey.

\section{Türkiye'de abortla ilişkili equid herpesvirus tip 1 izolatlarının $g B$ geninin kısmi sekansı}

Özet: Equid herpesvirus 1 (EHV-1), kısraklarda sporadik veya epidemik tarzda genellikle gebeliğin son trimesterinde görülen abort olgularından sorumlu başlıca etkendir. Bu araştırmada, yeni dizayn edilen bir primer çifti kullanılarak, ülkemizde 2011 yılındaki doğum sezonundaki abort salgınından izole edilen Türkiye (TR) EHV-1 saha suşlarının glikoprotein B $(g B)$ gen bölgesinin kısmi karakterizasyonu araştırılmıştır. Moleküler analiz sonuçları bu araştırmada izole edilen suşların, önceki yıllarda ülkemizde izole edilen EHV-1 suşlarına genetik olarak benzer; EHV-1 Avrupa suşlarıyla ise genetik yakınlığa sahip olduğunu göstermiştir. Ayrıca, bu araştırmada izole edilen suşlar ile GenBank veri tabanında kayıtlı diğer EHV-1 suşlarının aminoasit sekansları arasında farklılıklar tespit edilmiştir. Bu moleküler araştırma, ülkemizde EHV-1 enfeksiyonunun izlenmesi ve gelecekteki salgınlardan izole edilebilecek yeni suşların $g B$ gen bölgesindeki değişikliklerin patogenezi ve hastalığın gelişimi üzerine etkilerinin belirlenmesine 1şık tutacaktır.

Anahtar sözcükler: Abort, at, at herpesvirus tip 1 (EHV-1), glikoprotein B geni, Türkiye.

\section{Introduction}

Equid herpesvirus $1(\mathrm{EHV}-1)$ is a member of the Alphaherpesvirinae subfamily, family Herpesviridae (10) which is a major agent of large-scale outbreaks of abortion and perinatal/neonatal deaths as well as respiratory tract disease and, occasionaly neurological disorders $(15,29)$. EHV-1 abortions have been described as sporadic and epidemic cases in mares, generally during the last trimester of pregnancy $(5,25,27,33)$. In spite of routine vaccine applications, there is no solution to EHV-1 abortions due to latent mechanism to protect them completely. Thus, in addition to regular vaccinations, efforts on prevention and control of epidemic EHV-1 infection should focus on early diagnosis, development of management practices and quarantine in infected areas $(1,24)$.
The glycoprotein B $(g B)$ gene, which codifies for an envelope glycoprotein of 980 amino acid (aa), is located in the ORF 33 among the unique long region (UL) of EHV-1 genome, starting in the base pair 61432 and ending in 64374 (length 2942 bp). The $g B$ is highly conserved and is represented in all herpesvirus of human and animals. It is clearly known that the $g B$ is essential for the entry of the virus to the cell and is the principal viral antigen recognized by the host (28).

EHV-1 was first isolated during an outbreak of abortion in 1968 in Turkey (6). Subsequently, there have been reports on the epidemiology of EHV-1 based on an outbreak of abortion and respiratory disease $(3,4,17,34$, $35,36)$. In this report, a genetic analysis of EHV-1 field strains isolated from an abortion outbreak during the 2011 foaling season in vaccinated thoroughbred mares in 
Turkey was conducted using a novel primer set based on EHV-1 $g B$ gene

\section{Materials and Methods}

Samples and virus isolation: The virus isolation from the three placentas and a foetal lung obtained from four aborted foetuses from two studs located Marmara region, Turkey in 2011 were performed in equine dermis (ED) cell cultures. The ED cell cultures were grown in Dulbecco's Minimal Essential Medium (DMEM) (Biochrom, Germany) supplemented with $1 \% \mathrm{v} / \mathrm{v}$ foetal bovine serum (Biochrom, Germany) at $37^{\circ} \mathrm{C}$ in a $5 \%$ $\mathrm{CO}_{2}$ atmosphere and subsequently it was used for virus isolation.

Phylogenetic analysis of the $g B$ gene sequences of TR EHV-1 strains: The forward (5'-CTA ACC GCA CCT ACG ACC-3'; Location: 62852-62869) and reverse (5'-TAC ACC TCC AGG GGC AGA-3'; Location: 63656-63639) primers were designed based on equine herpesvirus 1 strain V592 complete genome (AY464052) for partial characterization of the $g B$ gene segment $(805$ bp). The Qiagen Fast Cycling PCR kit (Cat.No.203745, Qiagen, Germany) was used for the amplification as recommended by the manufacturer. The amplified DNA product was purified using a High Pure PCR Product Purification kit (Roche, Germany) and sequenced using a commercial genetic analyser, ABI 3130XL, (Refgen Biotechnology, Technopolis of Middle East Technical University, Ankara, Turkey). The sequences from both directions were assembled for each isolate to obtain consensus sequences, which were then used in multiple alignments of sequences from different isolates using BioEdit v.7.0.9.0 (18). The phylogenetic analysis was constructed using a the Maximum Likelihood method based on the Tamura 3-parameter model in the Mega V5.0 software package program $(31,32)$. Bootstrap values were calculated from 1000 replicates with random seeds.

\section{Results}

The four sequences identified in this study were assigned in GenBank under accession numbers of TRGEA-11 (JX416465), TR-MCA-11 (JX416466), TR-R12 (JX416467) and TR-McllA-12 (JX644987) and, then compared the partial sequences of four TR EHV-1 strains with the sequences of previous EHV-1 strains published in the GenBank database and to each other. The results on comparison of the partial sequences of EHV-1 $g B$ gene are shown in Figure 1.

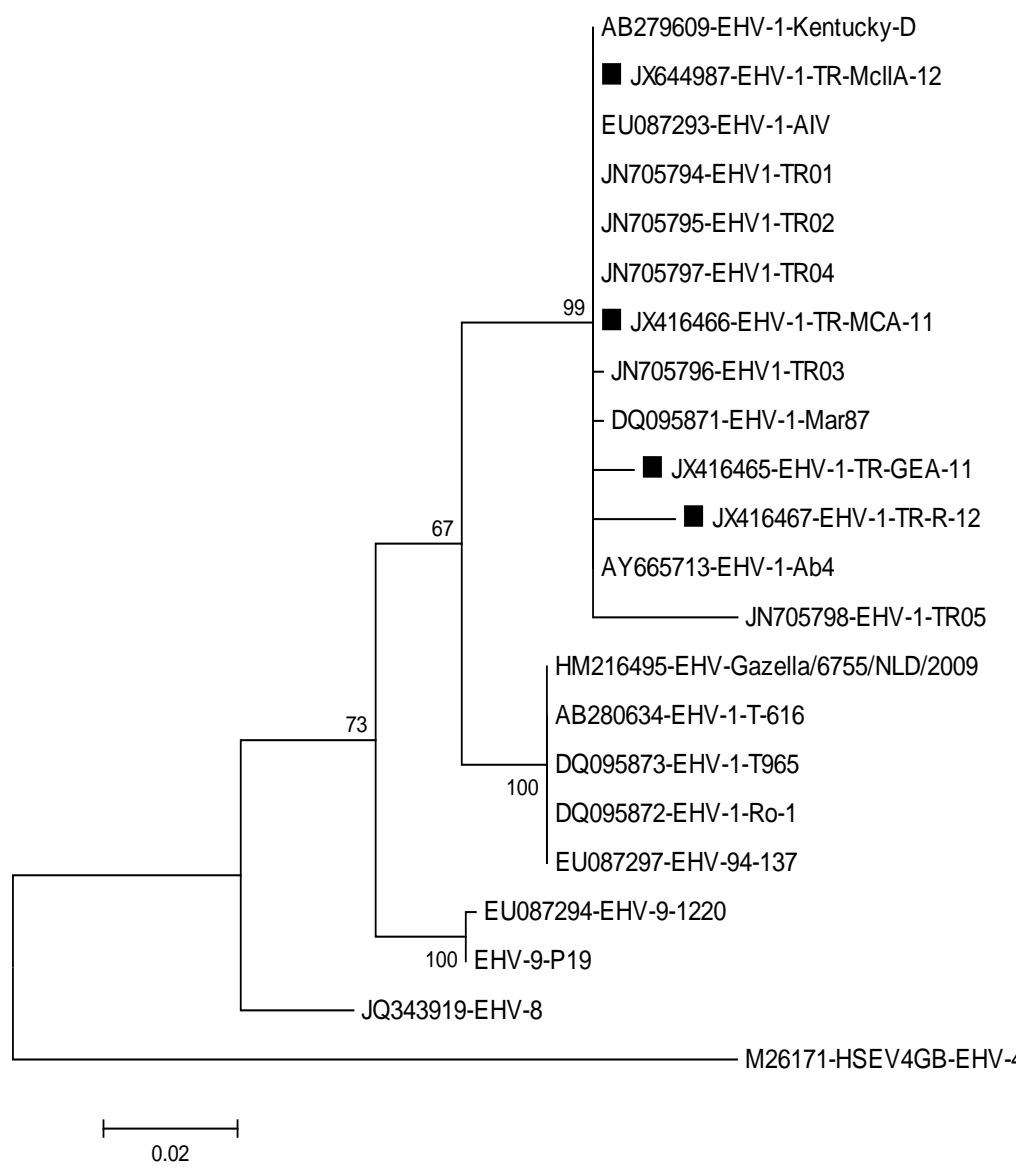

Figure 1. Phylogenetic tree for the $g B$ gene of EHV-1 strains was constructed in BioEdit. Bar: Number of base substitutions per site. Şekil 1. BioEdit programı ile oluşturulan EHV-1 suşlarının $g B$ gen bölgesinin filogenisi. 


\begin{abstract}
AV665713-EHV-1-Ab4 EU087297-EHV-94-137 J $\times 416467-E H V-1-T R-R-12$ J $\times 41$ 6465-EHV-1-TR-GEA-11 JX416466-EHV-1-TR-HCA-11 JX644987-EHV-1-TR- HACllA-12 JN705798-EHV-1-TR05 JN705797-EHV1-TR04 JN705796-EHV1-TR03 JN705795-EHV1-TR02 JN705794-EHV1-TR01 EU087293-EHV-1-ATV AB279609-EHV-1-Kentucky-D DQ095871-EHV-1-Har87 HW21 6495-EHV-Gozella-6755-N AB280634-EHV-1-T-616 DQ095873-EHV-1-T965 DQ095872-EHV-1-Ro-1 EU087294-EHV-9-1220 EHV-9-P19

JQ343919-EHV-8

H26171-HSEV4GB-EHV-4
\end{abstract}

AV665713-EHV-1-Ab4 EU087297-EHV-94-137 J $\times 41$ 6467-EHV-1-TR-R-12 J $\times 416465-E H V-1-T R-G E A-11$ JX41 6466-EHV-1 -TR-HCA-11 JX644987-EHV-1-TR-HCClAA-12 JN705798-EHV-1-TR05 JN705797-EHV1-TR04 JN705796-EHV1-TR03 JN705795-EHV1-TR02 JN705794-EHV1-TR01 EU087293-EHV-1-ATV AB279609-EHV-1-Kentucky-D HW21 6495-EHV-Gozella-6755-N AB280634-EHV-1-T-616 DQ095873-EHV-1-T965 DQ095872-EHV-1-Ro-1 EU087294-EHV-9-1220 EHV-9-P19

JQ343919-EHV-8

AV665713-EHV-1-Ab4 EU087297-EHV-94-137 JX416467-EHV-1-TR-R-12 J×41 6465-EHV-1-TR-GEA-11 JX644987-EHV-1 -TR-HCNAA-12 JN705798-EHV-1-TR05 JN705797-EHV1-TR04 JN705796-EHV1-TR03 JN705795-EHV1 -TR02 JN705794-EHV1-TR01 EU087293-EHV-1-ATV DQ095871-EHV-1-Hhar87 HH21 6495-EHV-Gozella - 6755-N AB280634-EHV-1-T-616 DQ095873-EHV-1-T965 DQ095872-EHV-1-Ro-1 EU087294-EHV-9-1220 EHV-9-P19

JQ343919-EHV-8

H26171-HSEV4GB-EHV-4 DQ095871-EHV-1-Har87

H26171-HSEV4GB-EHV-4 J $\times 416466-E H V-1-T R-H C A-11$ AB279609-EHV-1-Kentucky-D
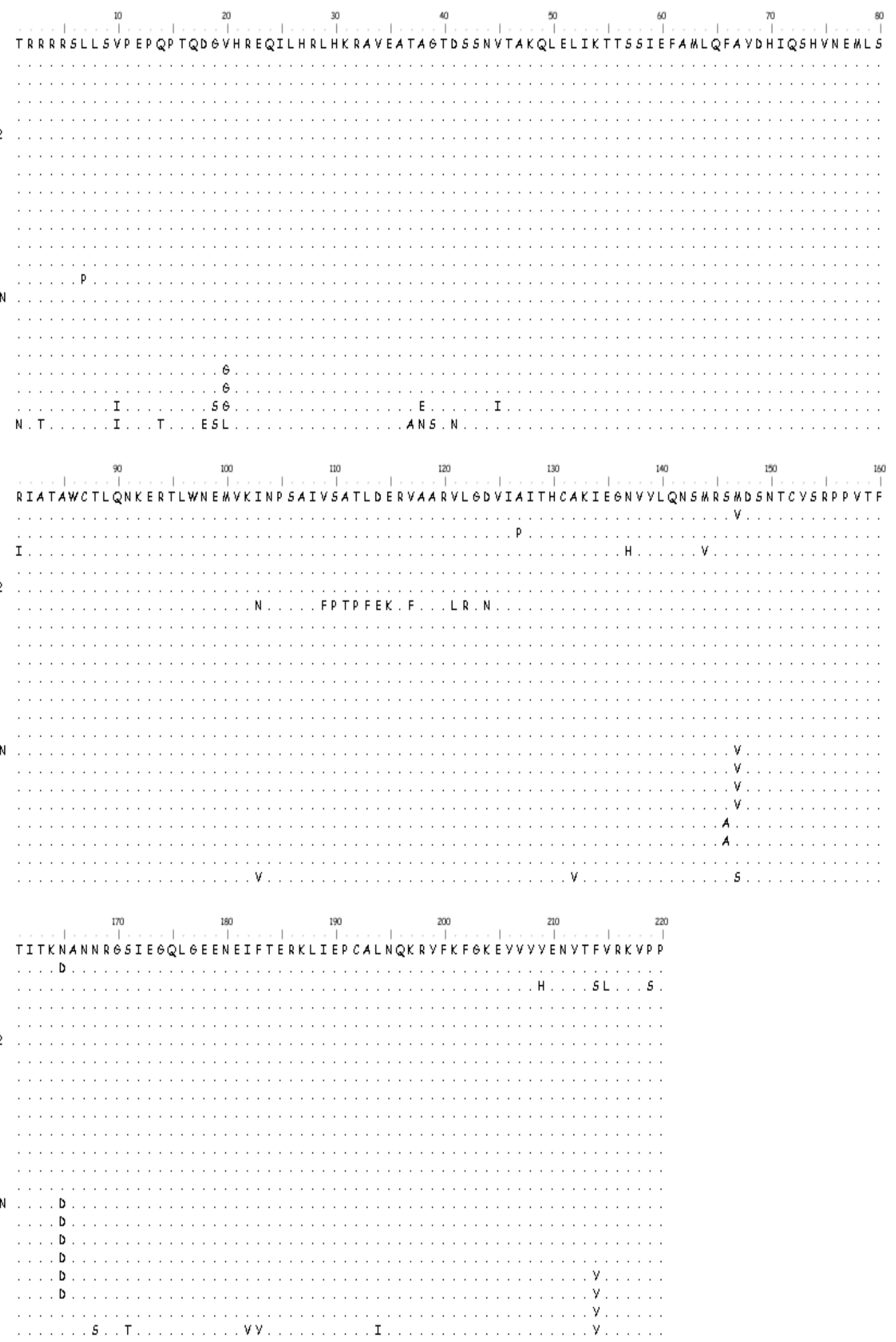

Figure 2. Alignment of the predicted aa sequences of TR EHV $-1 g B$ and some previous EHV-1 strains.

Şekil 2. Önceden izole edilen EHV-1 ve TR EHV-1 suşlarının $g B$ gen bölgelerine ait aminoasit dizilerinin karşılaştırması. 


\section{Discussion and Conclusion}

EHV-1-related abortions were examined using placenta and tissue from foetal or neonatal foal deaths worldwide $(13,21,30,33,34)$. The sequence analysis demonstrated that the TR EHV-1 isolates in the present study shared 98.2 to $100 \%$ and $92.7-100 \%$ nucleotide (nt) sequence identities with each other and with the sequences of the other published viruses, including the EHV-1 related viruses detected in non-equid hosts such as gazella, antilope and giraffe, respectively $(7,8,14,20$, $23)$. The sequence analysis suggested that the EHV-1 related viruses detected in zebra and non-equid hosts such as gazella, antilope and giraffe were represented a phylogenetically distinct group of EHV-1 (7, 8, 14, 20, 23), like the results described by Ghanem et al. (14) and, our TR EHV-1 strains were clustered in a separate branch along with European (EU) EHV-1 strains (98.6$100 \%$ nt identity). Moreover, the comparison with previously reported TR EHV-1 sequences (34) showed that TR EHV-1 strains during different years exhibit also a high degree of genetic homogeneity (96.7 to $100 \% \mathrm{nt}$ identity). It is likely that genetically identical TR EHV-1 strains during different years indicate that some indigenous strains are still circulating in Turkey.

The aa sequence comparisons between the TR EHV-1 strains examined here and EHV-1 strains available in GenBank showed that these sequences have 96-100\% homology, although there were some changes between the TR EHV-1 strains in this study and other EHV-1 strains, as shown in Figure 2. Herpesvirus $g B$ plays a primarily role in virus replication and pathogenesis $(2,11,26)$. Thus, future molecular studies should focus on effects of these differences at the aa level and determining the impact of sequence variations in the $g B$ gene of newly identified EHV-1 strains from future outbreaks on the pathogenesis and severity of disease. Furthermore, in future molecular studies, by examining the mutations in such genes as $g C, g D, g G$ and $O R F 64$ that are known to be responsible for viral replication, host specificity, immune response and pathogenesis (9, $12,16,19,22)$ in field isolates of EHV-1 obtained from different regions and by determining whether these mutations would increase the abortifacient ability of the virus, selection of viral strains for vaccine development may be more effectively employed.

In conclusion, the sequence analysis based on the $g B$ gene of the TR EHV-1 isolates indicates that predominantly EU EHV-1 strains are circulating in Turkey which is expected to be highly useful for monitoring of EHV-1 infection. Moreover, the sequence information for the $g B$ gene from field isolates of EHV-1 would be valuable the development of an effective vaccine against horse abortions caused by EHV-1 and EHV-4 as using one of these viruses as a vector.

\section{Acknowledgement}

This study has been supported by the Scientific Research Funds of Mustafa Kemal University, Hatay, Turkey (No.1201 M 0114). This study had been presented as a poster at World Equine Veterinary Association Intermediate Equine Congress, 19-21 September 2014, İstanbul, Turkey.

\section{References}

1. Allen GP (2002): Epidemic disease caused by equine herpesvirus-1: recommendations for prevention and control. Eq Vet Educ, 14, 136-142.

2. Arii J, Wang J, Morimoto T, et al. (2010): A single amino-acid substitution in herpes simplex virus 1 envelope glycoprotein $B$ at a site required for binding to the paired immunoglobulin-like type 2 receptor $\alpha$ (PILR $\alpha$ ) abrogates PILR $\alpha$-dependent viral entry and reduces pathogenesis. J Virol, 84, 10773-10783.

3. Ataseven VS, Bilge Dağalp S, Güzel M, et al. (2009): Prevalence of equine herpesvirus-1 and equine herpesvirus-4 infections in equidae species in Turkey as determined by ELISA and multiplex nested PCR. Res Vet Sci, 86, 339-344.

4. Avcı O, Yavru S, Tokgöz S, et al. (2014): Detection of antibodies against equine herpesvirus-1 and equine herpesvirus-4 in horses in Southeast Anatolia by indirect ELISA. Acta Sci Vet, 42, 1250.

5. Barrandeguy M, Parreno V, Chambers T, et al. (1999): Viral infections of horses in Argentina. 520-522. In: U Wernery, JF Wade, JA Mumford, OR Kaaden (Eds.), Proceedings of the 8th International Conference Equine Infectious Diseases, Dubai, UAE. R\&W Publications, Newmarket, UK.

6. Başkaya H, Keskintepe H, Doğruer M, et al. (1968): An outbreak of equine virus abortion in Turkey I. Isolation and identification of rhinopneumonitis virus in cell cultures. Vet J Ankara Univ, 15, 309-317.

7. Borchers K, Böttner D, Lieckfeldt D, et al. (2006): Characterization of equid herpesvirus 1 (EHV-1) related viruses from captive grevy's zebra and blackbuck. J Vet Med Sci, 68, 757-760.

8. Borchers K, Lieckfeldt D, Ludwig A, et al. (2008): Detection of equid herpesvirus 9 DNA in trigeminal ganglia of a Burchell's zebra from the Serengeti ecosystem. J Vet Med Sci, 70, 1377-1381.

9. Cowdhury S, Naderi M, Chouljenko VN, et al. (2012): Amino acid differences in glycoproteins $B(g B), C(g C), H$ $(g H)$ and $L(g L)$ are associated with enhanced herpes simplex virus type-1 (McKrae) entry via the paired immunglobulin-like type-2 receptor $\alpha$. Virol J, 9, 112.

10. Davison AJ, Eberle R, Ehlers B, et al. (2009): The order Herpesvirales. Arch Virol, 154, 171-177.

11. Eisenberg RJ, Atanasiu D, Cairns TM, et al. (2012): Herpes virus fusion and entry: A story with many characters. Viruses, 4, 800-832.

12. Fukushi H, Tomita T, Taniguchi A, et al. (1997): Gazelle herpesvirus 1: A new neurotropic herpesvirus immunologically related to equine herpesvirus 1 . Virology, 226, 34-44. 
13. Gerst S, Borchers K, Gower SM, et al. (2003): Detection of EHV-1 and EHV-4 in placental sections of naturally occuring EHV-1- and EHV-4-related abortions in the UK: use of the placental in diagnosis. Eq Vet J, 35, 430-433.

14. Ghanem YM, Fukushi H, Ibrahim ESM, et al. (2008): Molecular phylogeny of equine herpesvirus 1 isolates from onager, zebra and Thomson's gazelle. Arch Virol, 153, 2297-2302.

15. Gilkerson JR, Love DN, Whalley JM (1998): Epidemiology of equine herpesvirus abortion: searching for clues to the future. Aust Vet J, 76, 675-676.

16. Gryspeerdt AC, Vandekerckhove AP, Baghi HB, et al. (2012): Expression of late viral proteins is restricted in nasal mucosal leucocytes but not in epithelial cells during early-stage equine herpes virus-1 infection. Vet J, 193, 576-578.

17. Gür S, Yapıcı O (2008): Equine Herpesvirus type 1 and 4 in Individually Reared Horses in Central and Western Turkey. Acta Vet Brno, 77, 609-613.

18. Hall TA (1999): BioEdit: a user-friendly biological sequence alignment editor and analysis program for Windows 95/ 98/ NT. Nucleic Acids Symp. Series No. 41, 95-98.

19. Hussey GS (2012): Equine herpesvirus-1: What are we stil missing? Vet J, 193, 309-310.

20. Kasem S, Yamada S, Kiupel M, et al. (2008): Equine herpesvirus type 9 in giraffe with encephalitis. Emerg Infect Dis, 14, 1948-1949.

21. Kirisawa R, Endo A, Iwai H, et al. (1993): Detection and identification of equine herpesvirus-1 and -4 by polymerase chain reaction. Vet Microbiol, 36, 57-67.

22. Kydd JH, Davis-Poynter NJ, Birch J, et al. (2006): A molecular approach to the identification of cytotoxic $T$ lymphocyte epitopes within equine herpesvirus 1 . J Gen Virol, 87, 2507-2515.

23. Liu C, Guo W, Xiang W et al. (2012): Complete genomic sequence of an equine herpesvirus type $8 \mathrm{Wh}$ strain isolated from China. J Virol, 30, 5407.

24. Lunn DP, Davis-Poynter N, Flaminio MJBF, et al. (2009): Equine herpesvirus consensus statement. J Vet Int Med, 23, 450-461.

25. Matsumura T, Sugiura T, Imagawa H, et al. (1992): Epizootiological aspects of type 1 and type 4 equine herpesvirus infections among horse populations. J Vet Med Sci, 54, 207-211.

26. Neubauer A, Braun B, Brandmüller C, et al. (1997): Analysis of the contributions of the equine herpesvirus 1 glycoprotein $\mathrm{gB}$ homolog to virus entry and direct cell to cell spread. Virology, 227, 281-294.
27. Singh BK, Yadav MP, Uppal PK, et al. (1999): National assessment of equine herpesvirus-1 infection among equidae in India. 578-579. In: U Wernery, JF Wade, JA Mumford, OR Kaaden (Eds.), Proceedings of the 8th International Conference Equine Infectious Diseases, Dubai, UAE. R\&W Publications, Newmarket, UK.

28. Slater J (2007): Equine Herpesviruses. 134-153. In: D Sellon, M Long (Eds.), Equine Infectious Diseases, Chapter 13. Elsevier, Philadelphia, USA.

29. Smith KL, Allen GP, Branscum AJ, et al. (2010): The increased prevalence of neuropathogenic strains of EHV-1 in equine abortions. Vet Microbiol, 141, 5-11.

30. Szeredi L, Aupperle H, Steiger K (2003): Detection of equine herpesvirus-1 in the fetal membranes of aborted equine fetuses by immunohistochemical and in-situ hybridization techniques. J Comp Pathol, 129, 147-153.

31. Tamura K (1992): Estimation of the number of nucleotide substitutions when there are strong transition-transversion and $G+C$-content biases. Mol Biol Evol, 9, 678-687.

32. Tamura K, Peterson D, Peterson N, et al. (2011): MEGA5: molecular evolutionary genetics analysis using maximum likelihood, evolutionary distance, and maximum parsimony methods. Mol Biol Evol, 28, 2731-2739.

33. Tekelioğlu BK, Matsumura T, Tsujimura K, et al. (2006): Detection of equine herpesvirus type 1 (EHV-1) DNA organs of neonatal dead foals in Turkey. J Eq Sci, 17, 23-26.

34. Turan N, Yıldırım F, Altan E, et al. (2012): Molecular and pathological investigations of EHV-1 and EHV-4 infections in horses in Turkey. Res Vet Sci, 93, 1504-1507.

35. Yılmaz S, Girgin H, Demiryonguç A, et al. (1995): $E H V$ 1 infection in purebred English mares in Türkiye Jokey Culub (TJK) Izmit farm, protective vaccinations and result obtained. Etlik Vet Mikrobiyol Derg, 8, 230-237.

36. Yilmaz H, Altan E, Turan N, et al. (2012): First report on the frequency and molecular detection of neuropathogenic EHV-1 in Turkey. J Eq Vet Sci, 32, 525530.

Geliş tarihi: 16.12.2014 / Kabul tarihi: 16.10.2015

Address for correspondence:
Assoc. Prof. Dr. Veysel Soydal ATASEVEN
Mustafa Kemal University,
Faculty of Veterinary Medicine,
Department of Virology, Hatay, Turkey;
E-mail: soydalata@hotmail.com

Address for correspondence:

Mustafa Kemal University,

Faculty of Veterinary Medicine,

Department of Virology, Hatay, Turkey.

E-mail: soydalata@hotmail.com 